\title{
Accounting Ethics Education: What And How To Teach?
}

\author{
Amelia Limijaya \\ Accounting Department, Faculty of Economics, Parahyangan Catholic University \\ Bandung, West Java, Indonesia \\ amelia.limijaya@unpar.ac.id
}

\begin{abstract}
For academics, accounting ethics education is a challenging field, not only because of the common perception that it is considered secondary to accounting technical courses but also due to inconclusive results of its effectiveness on ethical behavior as well as uncertainty of what and how to teach. However, the recurring occurrence of accounting scandals as well support from accounting professional bodies on the importance of ethics in accounting curriculum, has contributed to the increasing attention given to accounting ethics. This paper tries to contribute to the growing accounting ethics literature by reviewing the contents and learning methods. Eleven topic categories are suggested, along with fifteen learning methods which are inventoried from a number of literatures. Academics should try to discover interesting and unconventional methods to teaching ethics, to equip the traditional methods of teaching. It should be noted however, that the effectiveness of accounting ethics education does not rely only on having proper teaching materials and methods, but also on the institutional support and the learners' commitment. Finally, three areas are identified to improve accounting ethics education, i.e. to develop a more principlesbased approach, to shift the focus of ethics education to prevent ethical failures, as well as to take on a greater role of business ethics in general, including accounting ethics, to the society as a whole. Knowing the what and how aspects is expected to be a start in improving and fostering accounting ethics education.
\end{abstract}

\section{Keywords: accounting ethics education, teaching materials, teaching methods.}

Abstrak. Bagi akademisi, pendidikan etika akuntansi merupakan area yang menantang, bukan saja karena terdapat persepsi umum bahwa area ini dianggap sekunder dibandingkan mata kuliah teknis akuntansi, tetapi juga karena hasil yang inkonklusif terkait efektivitas terhadap perilaku etis maupun ketidakpastian materi dan teknik pengajaran. Namun, dengan berulangnya skandal akuntansi serta adanya dukungan dari badan asosiasi profesi akuntansi mengenai pentingnya etika dalam kurikulum akuntansi, perhatian terhadap etika akuntansi semakin meningkat. Artikel ini mencoba memberikan kontribusi terhadap literatur etika akuntansi dengan menelaah aspek isi dan metode pembelajaran. Terdapat sebelas kategori topik dan lima belas metode pembelajaran yang disarankan, berdasarkan telaah literatur. Akademisi perlu menemukan metode pembelajaran yang menarik dan tidak konvensional, untuk memperlengkapi metode pengajaran tradisional. Namun demikian, perlu diingat bahwa efektivitas dari pendidikan etika akuntansi tidak hanya bergantung pada penyediaan materi dan metode pembelajaran yang tepat, tetapi juga dukungan institusi dan komitmen dari pembelajar. Pada akhirnya, terdapat tiga area yang diidentifikasi dapat meningkatkan pendidikan etika akuntansi, yaitu mengembangkan pendekatan yang lebih berbasis prinsip, mengubah fokus untuk mencegah kegagalan etika, serta mengampu tanggung jawab etika bisnis yang lebih luas, termasuk di dalamnya etika akuntansi, terhadap masyarakat secara keseluruhan. Dengan mengetahui aspek apa dan 
bagaimana, diharapkan dapat menjadi langkah awal untuk meningkatkan dan mempercepat perkembangan pendidikan etika akuntansi.

\section{Kata kunci: pendidikan etika akuntansi, materi pengajaran, metode pengajaran.}

\section{A. Introduction}

Accounting ethics education is an area that has been gaining much attention since the emergence of corporate scandals. Various efforts have been performed by professional accounting bodies, government, as well as academic institutions in order to increase the awareness of the importance of ethics in the accounting profession, one of which is through accounting ethics education. A number of professional bodies surveyed by Jackling, et al. (2007) agreed that ethics can and should be taught prior to becoming accounting professionals. Another research conducted by Ghazali (2015) found that ethical judgment made by accountants is influenced by ethics instruction, thus gives the justification for the importance of accounting ethics course. However, even though it is supported that ethics education does increase the awareness of ethical issues, it is still unclear whether ethics education would in turn lead to ethical behavior (Koumbiadis \& Pandit 2014). This is also supported by Jonson, McGuire and Cooper (2016) who stated that other than ethics education, attitudes and behavior are also influenced by ethical values held by individuals, which are shaped by cultural, family as well as religious factors. Although there have been mixed results with regards to the effectiveness of ethics education and the extent to which ethics education would impact ethical behavior, it does not mean that ethics education can be abandoned in the accounting curriculum.

Incorporating accounting ethics in accounting curriculum has not been an easy task. There are some obstacles to implementing accounting ethics education commonly faced by academics, to name a few: uncertainty of materials and pedagogy, lack of resources (human, time), limited knowledge and competencies on the subject area, the somewhat secondary status of accounting ethics compared to accounting technical skills hence no space left in the curriculum for accounting ethics, and so on (Abdolmohammadi \& Reinstein 2012; Levy \& Mitschow 2008; Blanthorne 2017; Graham, et al. 2014). Due to these reasons, accounting ethics often does not get the attention it deserves and is put aside to prioritize accounting technical-related skills. In an ideal state, “... ethics education should be taught as part of a broad based program that includes three elements: (1) an introduction to ethical thought early in the degree program; (2) ethical discussion in existing accounting courses relevant to the topics at hand; and (3) a dedicated capstone course that ties together previous ethics material" (Piper et al., 1993 \& Armstrong, 1993 cited in Dellaportas 2006). There seems to be a quite big gap between the ideal versus the current state of accounting ethics education, which can be viewed as rooms for academics to improve on the subject matter, in collaboration with practitioners/ professional accountants, as the later are also committed to developing accounting ethics and needs to be involved (Jackling, et al. 2007; Abdolmohammadi \& Reinstein 2012).

Nevertheless, there are disagreements between academics and practitioners in terms of the coverage of ethics education which result from divergent views from both parties with regards to the differences in the perceived importance of the topics as well as ethics education itself (Rezaee, et al. 2015). These disagreements may result from the different perspectives between academics and practitioners of what accounting ethics 
education should constitute of, i.e. its intended goal or learning outcome. Unlike accounting technical-related courses which generally have clear and straightforward objectives, the learning outcome of accounting ethics course is somewhat vague and difficult to measure (Holmes, Marriott \& Randal 2012). A recent research conducted by Miller and Shawver (2018) found that accounting ethics education in the UK has not changed much for the past two decades. According to West and Buckby (2018), the changes needed in accounting ethics education should come from professional accounting bodies. Thus, developing and improving accounting ethics education is a challenging process yet can be rewarding.

This paper tries to contribute to the growing accounting ethics literatures by reviewing the what and how aspects of accounting ethics education, i.e. the content and the learning approach/ method. In addition to that, the future or direction of accounting ethics education is also discussed. It is expected that by knowing what and how to teach accounting ethics course, the development and improvement of accounting ethics education can be fostered.

\section{B. Literature Review}

In a wider context, business ethics has undergone some development phases, as can be seen in Table 1 below. The topic of accounting ethics education can be classified in phase 5 agenda number 1, i.e. academic programs, for example how to incorporate it in the curriculum. In order to do this, input from related research area (agenda number 2 ) is surely needed. This is what this paper is essentially trying to achieve, to improve accounting ethics education program in the curriculum by taking into account research results on accounting ethics.

Table 1 Developmental Phases of Business Ethics

\begin{tabular}{|c|c|c|}
\hline Phase & Period & Focus of business ethics \\
\hline 1 & $1920+$ & $\begin{array}{l}\text { Theological and religious perspective raising questions on just wages and } \\
\text { the morality of capitalism. }\end{array}$ \\
\hline 2 & $1960+$ & $\begin{array}{l}\text { Growing public awareness of social and ecological impacts of corporate } \\
\text { activity. }\end{array}$ \\
\hline 3 & $1970+$ & $\begin{array}{l}\text { The discipline of business ethics emerged as a distinct paradigm with } \\
\text { contributions from philosophers and political economists on the subjects } \\
\text { of business ethics. }\end{array}$ \\
\hline 4 & $1980-1985$ & $\begin{array}{l}\text { Evolved from a field of academic inquiry to debates in the world of } \\
\text { practice. }\end{array}$ \\
\hline 5 & $1985+$ & $\begin{array}{l}\text { Agenda for action that can be classified according to two classifications: } \\
\text { 1. academic programs } \\
\text { 2. higher more robust research }\end{array}$ \\
\hline
\end{tabular}

Source: IFAC 2006, p. 35

Efforts to improve accounting ethics education may well start with its purpose. There are some literatures on what accounting ethics education should aim at. For example, "... the goals of accounting ethics education should be to stimulate a student to ... recognize issues in accounting that have ethical implications and ... develop a sense of moral obligation or responsibility“ (Loeb 1988 cited in Levy \& Mitschow 2008). The goal of ethics education is also dependent on whether the course is more of a philosophical or practical in nature, i.e. more oriented towards reasoning or improving awareness on ethical issues, or even combining the two (Weber 1990 \& Marnburg 2003 
cited in McDonald 2004). Another suggestion on the goals of ethics education comes from Callahan (1980) as cited in McDonald (2004), which consist of stimulating moral imagination, recognizing ethical issues, eliciting a sense of moral obligation, developing analytical skills, and tolerating and reducing disagreement and ambiguity. Meanwhile, Holmes, Marriott and Randal (2012) stated that ethics education should make individuals to become more aware of ethical dilemmas they may encounter, thus can help them in making the right decision. In a 2006 report, IFAC (International Federation of Accountants) highlighted four goals of learning ethics, i.e. establishing the intellectual background to understand ethical positions, developing ethical sensitivity, developing ethical competence and skills, and translating into ethical behavior. Hence, in general, the goal of accounting ethics education should be directed towards helping individuals to behave ethically and to make the right ethical decision.

The goals of ethics education as discussed above, could then be used as the foundation to develop the framework of learning ethics, as developed by IFAC through its proposed Ethics Education Framework (IFAC 2006). The summary of Ethics Education Framework (EEF) can be portrayed in Figure 1 below. Besides this framework, IFAC also has two standard-setting bodies relevant to ethics education, namely the International Ethics Standard Board for Accountants (IESBA) which produces the International Code of Ethics for Professional Accountants and the International Accounting Education Standards Board which publishes the International Education Standards (IES).

Figure 1 IFAC's Ethics Education Framework

\begin{tabular}{|c|c|c|c|c|}
\hline \multirow{4}{*}{$\begin{array}{l}\text { The Learning } \\
\text { Continuum: } \\
\text { Pre- and Post } \\
\text { Qualifying } \\
\text { Stages }\end{array}$} & Stage & Objective of stage & How to teach & Focus of content \\
\hline & $\begin{array}{c}\text { Stage 4: } \\
\text { Ethical behavior }\end{array}$ & $\begin{array}{l}\text { To understand organizational } \\
\text { and situational contexts and to } \\
\text { sharpen one's ethical } \\
\text { competence in translating } \\
\text { knowledge and sensitivity into } \\
\text { behavior. }\end{array}$ & $\begin{array}{l}\text { Continuous professional } \\
\text { ethical training. }\end{array}$ & $\begin{array}{l}\text { Factors affecting ethical } \\
\text { decision-making and } \\
\text { ethical behavior }\end{array}$ \\
\hline & thical judgment & $\begin{array}{l}\text { To integrate knowledge of } \\
\text { ethics with sensitivity in order } \\
\text { to develop competence in } \\
\text { ethical judgment and } \\
\text { decisions. }\end{array}$ & $\begin{array}{l}\text { A separate required or optional } \\
\text { capstone module/ course in } \\
\text { ethics. }\end{array}$ & $\begin{array}{l}\text { Application of ethical } \\
\text { theories, social } \\
\text { responsibilities, code of } \\
\text { professional conduct } \\
\text { and other ethical } \\
\text { decision models to } \\
\text { ethical dilemmas }\end{array}$ \\
\hline & sensitivity & $\begin{array}{l}\text { Sensitize learners to ethical } \\
\text { issues and threats in the } \\
\text { relevant functional disciplines } \\
\text { of accounting. }\end{array}$ & $\begin{array}{l}\text { Integration of ethical issues } \\
\text { across existing subject matter } \\
\text { such as financial accounting, } \\
\text { managerial accounting, } \\
\text { auditing and taxation. }\end{array}$ & $\begin{array}{l}\text { Common issues and } \\
\text { dilemmas facing } \\
\text { accountants in practice } \\
\text { e.g. tax evasion. }\end{array}$ \\
\hline & & $\begin{array}{l}\text { To develop ethical intelligence } \\
\text { by attaining the necessary } \\
\text { knowledge in ethical concepts } \\
\text { and theories relating to the } \\
\text { accountant's work. }\end{array}$ & $\begin{array}{l}\text { A separate required module in } \\
\text { ethics taught early in the } \\
\text { program. }\end{array}$ & $\begin{array}{l}\text { Traditional theories of } \\
\text { ethics, virtues, and } \\
\text { moral development }\end{array}$ \\
\hline
\end{tabular}

Source: IFAC 2006, p. 99

West (2017) shared his perspective with regards to the IFAC's current approach in dealing with ethics education. He found several limitations to the approach taken by IFAC: (1) the dominance of the rule-based approach compared to the principles-based (2) inadequacy of understanding of morality, i.e. Rest's Four Component Model, which consists of moral sensitivity, moral judgement, moral motivation and moral character (3) inherent limitations in the approach to develop ethical skills, which result in failures 
to prevent accounting misstatements and scandals. Previously, Levy and Mitschow (2008) also favored a more principles-based approach to learning ethics and developing ethical standards. One of the characteristics of principle-based approach is the exercise of judgments, and this is the essence of accounting, “ ... accounting discourse ... is essentially an ethical discourse. The operationalization of accounting objectives and characteristics is mainly one of making value judgments" (Williams 2015, p. 22). Some examples of value judgments made by accountants were also provided (Williams 2015).

\section{Research Method}

This paper is basically a critical review of accounting ethics education literatures, specifically in terms of content and method of teaching. The reviewed literatures may come in the form of journal articles, textbooks, standards/ guidelines, reports, as well as collection of best practices in the field of accounting ethics education. Analysis and comments on the relevant literatures are provided in the next section, along with the suggested improvements in the subject matter and for accounting ethics in general.

\section{Discussion}

The discussion will be divided into several sections. The first two sections discuss the suggested topics as well as teaching methods for accounting ethics course. Next, some improvement areas of accounting ethics education are provided, followed by the discussion on the need to take accounting ethics to a broader view. Lastly, concluding comments are provided to sum up the discussion.

\section{Accounting Ethics Education: What to Teach}

There are some suggestions regarding the content of accounting ethics education, based on a number of literatures reviewed by the author (Abdolmohammadi \& Reinstein 2012; Levy \& Mitschow 2008; Blanthorne 2017; Rezaee, et al. 2015; Chawla, et al. 2015; Dellaportas 2006; Klimek \& Wenell 2011; Dzuranin, Shortridge \& Smith 2013; Shaub 2017; Barker 2014; Huehn 2016; Taylor 2013; Heller \& Heller 2011; Boose \& Dean 2011; Franks \& Spalding 2013; Kelly 2017; Klein 2016; Mintz \& Morris 2014; AACSB Ethics Education Task Force 2004; AACSB 2017; AACSB 2016b; IAESB 2017; IFAC 2006). Some topics are mentioned quite often, whether using the same wording or under different names yet essentially mean the same. The author then analyzed and grouped the various topics into categories, resulting in 11 categories as summarized in Table 2, in a particular order.

Table 2 Categories of Accounting Ethics Course Topics

\begin{tabular}{|c|l|l|}
\hline No. & \multicolumn{1}{|c|}{ Categories } & \multicolumn{1}{|c|}{ Topics } \\
\hline 1 & Ethics theories & $\begin{array}{l}\text { Theories of ethics, ethics philosophy, moral } \\
\text { reasoning, moral development rules- and } \\
\text { principles-based approach to ethics, ethical } \\
\text { reasoning }\end{array}$ \\
\hline 2 & $\begin{array}{l}\text { Judgment and decision } \\
\text { making }\end{array}$ & $\begin{array}{l}\text { Ethical judgment, decision-making process, } \\
\text { decision-making models, ethical reasoning, } \\
\text { ethical decision-making }\end{array}$ \\
\hline 3 & Responsibility of business & Business environment, corporate social \\
\hline
\end{tabular}




\begin{tabular}{|c|l|l|}
\hline & & $\begin{array}{l}\text { responsibility, ethical principles in business, } \\
\text { public interest, sustainability, environmental } \\
\text { issues }\end{array}$ \\
\hline 4 & Regulatory framework & $\begin{array}{l}\text { Legal aspect surrounding business, regulation } \\
\text { surrounding the accountancy profession, } \\
\text { compliance with standards and laws }\end{array}$ \\
\hline 5 & Professional codes of conduct & $\begin{array}{l}\text { Ethical principles of professional accountants, } \\
\text { ethical codes of professional accountants, } \\
\text { professional obligations, conflict of interest, } \\
\text { ethical standards of professional accountants, } \\
\text { accounting profession codes of conduct }\end{array}$ \\
\hline 6 & $\begin{array}{l}\text { Corporate code of ethics and } \\
\text { governance }\end{array}$ & $\begin{array}{l}\text { Corporate governance, corporate code of ethics, } \\
\text { record retention, corporate environment, } \\
\text { corporate cultures }\end{array}$ \\
\hline 7 & Whistleblowing & $\begin{array}{l}\text { Whistleblowing, whistleblower protection, duties } \\
\text { as a whistleblower }\end{array}$ \\
\hline 8 & Ethical issues in practice & $\begin{array}{l}\text { Ethical dilemmas, ethical challenges, ethical } \\
\text { issues, ethics cases, ethical threats and safeguards }\end{array}$ \\
\hline 9 & $\begin{array}{l}\text { Corporate scandals, fraud, } \\
\text { earnings management }\end{array}$ & $\begin{array}{l}\text { Financial/ accounting scandals, corporate } \\
\text { failures, fraud, earnings management, corruption, } \\
\text { cheating, collusion, greed, discreditable acts }\end{array}$ \\
\hline 10 & Leadership & $\begin{array}{l}\text { Ethical leadership, leadership theories, moral } \\
\text { leadership, moral exemplars, moral courage }\end{array}$ \\
\hline 11 & Others & $\begin{array}{l}\text { Examples: communication skills, investor } \\
\text { protection, informal ethical discourse in entry } \\
\text { level and junior accountants, integrated thinking, } \\
\text { international issues }\end{array}$ \\
\hline
\end{tabular}

Source: processed by author

The order in which the topics are discussed are based on a deductive approach, i.e. starting from general to specific. Students should start the accounting ethics course by understanding what ethics is, then followed by the theories related with ethical judgment and decision making. The discussion is narrowed down to business context: its environment and responsibilities, including regulatory aspect. Then, even more specific, the codes of conduct governing professional accountants are discussed, followed by ethics in terms of a corporation. Whistleblowing could be included in category number 6 , but here it is shown separately as it may warrant its own discussion. Next, ethical issues commonly faced in practice are discussed, along with ethical failures such as accounting scandals, fraud and earnings management. The penultimate topic on ethical leadership deserves a spot in the course, as one of the factors that could prevent ethical failures from taking place is moral courage. Lastly, other topics can be regarded as special topics which may be modified or adjusted according to the needs, thus giving the course a flexibility, to some extent.

\section{Accounting Ethics Education: How to Teach}

After identifying what to teach, the next step is to determine how to teach, i.e. teaching methods or strategies. Similarly, the author also reviewed several literatures (IFAC 2006; Utama 2018; IAESB 2017; Fort 2016; Davis 2017; Weybrecht 2016; 
Kelly 2017; Sisaye 2011; Christensen, et al. 2007; Hejase \& Tabch 2012; Shapiro \& Hassinger 2007; O'Leary 2012; Taylor 2013; Perri, et al. 2009; Lawter, Rua \& Guo 2014; Shaub 2017; Dzuranin, Shortridge \& Smith 2013; Chawla, et al. 2015; Graham, et al. 2014; Abdolmohammadi \& Reinstein 2012; Levy \& Mitschow 2008) to inventory some of the available methods to teach accounting ethics and then grouped them accordingly. The result is as follows (in no particular order):

Table 3 Accounting Ethics Teaching Methods

\begin{tabular}{|c|c|c|}
\hline No. & Methods & Explanations \\
\hline 1 & Case study & Case analysis, case studies, case assignments \\
\hline 2 & $\begin{array}{l}\text { Debates, discussion, } \\
\text { presentation }\end{array}$ & Debates, class discussions, group presentations \\
\hline 3 & Games & Gamification \\
\hline 4 & Illustrations, vignettes & $\begin{array}{llll}\text { Classroom vignettes, ethical decision-making } \\
\text { illustrations }\end{array}$ \\
\hline 5 & Independent learning & Independent research on ethics-related topics \\
\hline 6 & Informal approach & $\begin{array}{l}\text { Out-of-class informal discussions, ethics kudos, } \\
\text { ethics dinner, out-of-class experience }\end{array}$ \\
\hline 7 & Internship & Work-based placements, mandatory internship \\
\hline 8 & Lecture & Traditional lecturing \\
\hline 9 & Online learning & Make use of online course management system \\
\hline 10 & Project & $\begin{array}{l}\text { Group projects, capstone project, ethics research } \\
\text { project, community service (social responsibility) } \\
\text { project, collaborative project, service learning } \\
\text { project, student-led organization project }\end{array}$ \\
\hline 11 & Reading & $\begin{array}{l}\text { Reading textbooks/ journals/ articles, summarizing, } \\
\text { preparing answer to textbook questions, written } \\
\text { assignments }\end{array}$ \\
\hline 12 & Reflective learning & $\begin{array}{l}\text { Personal journal, patchwork text, reflection journal, } \\
\text { work logs, personal development portfolios, diaries }\end{array}$ \\
\hline 13 & Role playing & Role playing, simulation \\
\hline 14 & Sharing by guest speaker & $\begin{array}{l}\text { Sharing session from guest speaker (practitioner) on } \\
\text { a particular topic }\end{array}$ \\
\hline 15 & Videos, films & Playing relevant videos, films \\
\hline
\end{tabular}

Source: processed by author

Some teaching methods are quite straightforward, such as lecture, case study, reading etc. However, there are several unconventional methods, for example the use of games/ gamification, which is a creative learning method that is getting more popular nowadays. Another one is the informal approach which takes place outside of classroom and can be either graded or not. Some literatures also highlighted the importance of reflective learning to studying ethics, where students keep some kind of personal journals/ diaries and evaluate themselves. Meanwhile, Christensen, et al. (2007) gave some examples of how the Financial Times top 50 global business schools organize ethics, corporate social responsibility and sustainability education, which could be used as a guidance or benchmark. These alternative and interesting ways of teaching ethics should be considered in addition to traditional teaching methods. In relation to the discussion on accounting ethics topics, a particular teaching method may be suitable for 
a particular topic, such as lecturing on more theoretical topics, or it could be that several teaching methods are utilized to discuss a certain topic.

As with other courses, a combination of active and passive methods is needed to teach accounting ethics course, with more weight probably should be directed to active method, as found out by O'Leary (2012) to be more effective. The support also comes from Sisaye (2011), who suggested a consequential-conflictual method to teach accounting ethics. This method is derived from double loop learning strategy and emphasizes a teaching method which is more practical, applied, and experiential. The support for a more experiential learning also comes from Lawter, Rua, and Guo (2014). Two examples of experiential learning methods found in Table 3 are internship and projects. The variety of teaching methods comes from the fact that there are several learning styles preferred by an individual: VARK, which stands for visual, aural/ auditory, reading/ writing and kinesthetic (Fleming and Mills 1992 cited in Graham, et al. 2014). Further, Lawter, Rua, and Guo (2014) suggested that students should try to study using learning styles not preferred by them (outside of their comfort zone), in order to stimulate deep learning, although this could be challenging. IFAC (2006) also pointed out the importance of collaborative learning techniques in accounting ethics education that involve other aspects outside of teaching ethics per se, such as leadership, decision making, trust building, communication and conflict management (p. 103). Finally, instructors may also benefit from practical tips in teaching ethics as highlighted by Weybrecht (2016), which can be summarized as follows: allocate time for it, make it practical and experiential, and engage the students more.

\section{Improving Accounting Ethics Education}

After addressing the what and how aspects of teaching accounting ethics as discussed above, this section will focus on discussing two things that could improve accounting ethics education: to develop an alternative philosophical basis and to shift the focus to prevent ethical failures. An alternative philosophical basis to accounting ethics is given by West (2017), by employing an Aristotelian approach which consists of three main principles: (1) Eudaimonia - the ultimate good, the pursued goal (2) excellences of intelligence and (3) excellences of character, which consists of developing courage and justice. As mentioned in the previous section, moral courage is something that seems missing in the area of ethics education (AACSB 2004). West (2017) then continued his proposed approach by discussing its implications to accounting ethics education. The major highlight is that the excellences of intelligence and character are optimized at different stagess, the former is best developed during formal education, whereas the latter is during professional work, as depicted in Figure 2. Therefore, accounting ethics education in accounting curriculum (as part of formal education), can be structured to focus more on the development of excellences of intelligence (e.g. ethical awareness, reasoning), but without overlooking the excellence of character aspect as well, although it may not be blossomed yet at this stage as it requires exposure to practical environment. Consequently, students should also be prepared by getting them used to exercising their own judgment in an ethical situation, thus supports the view of a more principles-based approach to accounting ethics education. 


\section{Figure 2 The Aristotelian Perspective of Accounting Ethics}

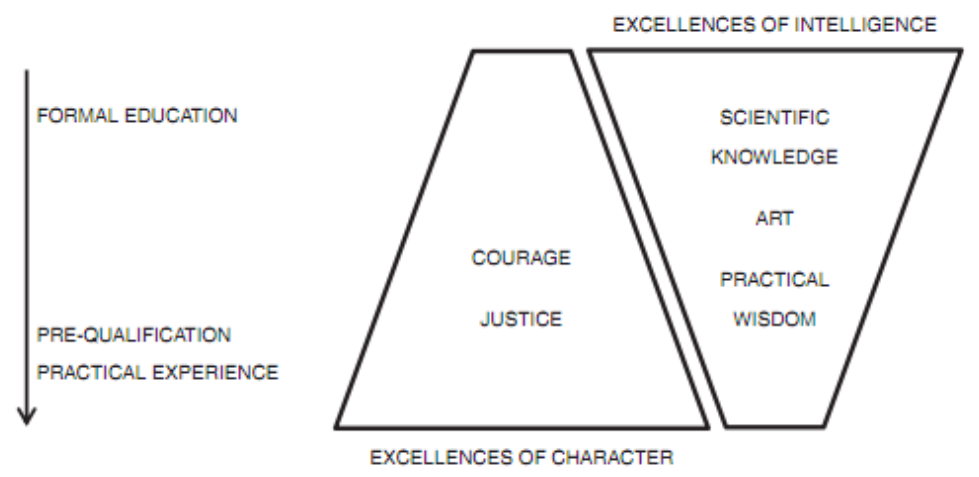

Source: West 2017, p. 346

The second area for improvement is through a shift in the focus of accounting ethics education to prevent ethical failures. This idea comes from Burns, Tackett and Wolf (2015) who suggested that since there is uncertainty of whether ethics education would result in an ethical behavior, it would probably be better to shift the focus to how to best prevent ethical failures. Several ethics-threatening factors that could potentially contribute to ethical failures are (Jackling, et al. 2007; IFAC 2006): self-interest, failure to maintain objectivity and independence, improper leadership and poor organizational culture, lack of ethical courage, lack of ethical sensitivity, failure to exercise or inappropriateness of professional judgment, failure to withstand advocacy threats, lack of competence, lack of organizational and peer support, and lack of professional body support. These factors should be considered when designing the content and delivery method of ethics education, though some may be uncontrollable by academics. For example, to tackle the professional judgment issue, students should be given more chances to apply their judgment through a more principles-based approach to ethics education. Another example would be to build leadership skills among students, as suggested by Kelly (2017), by integrating leadership topics in the course, so as to build courage to act ethically as well. Ethics education may also benefit from knowing the factors that may affect individual's moral judgment development (Dellaportas 2006) and how to best nurture them, so as to prevent ethical failures from taking place. In summary, it appears that there is a view that ethics education should move towards a more positive (explain and predict behavior) rather than normative (prescriptive) approach.

\section{A Broader Perspective}

The two areas as discussed above may be considered as short-term approach to improving accounting ethics education. In long-term, however, there is an expectation of a much more inclusive nature of business education, including accounting. In 2016, AACSB issued a report on the future of business education, which consists of a series of new vision: catalysts for innovation, co-creation of knowledge, hubs of lifelong learning, leaders on leadership, and enablers of global prosperity. Business is expected to take on a greater role, not just to create wealth, but more importantly to strengthen its leadership role and to positively impact wider society (AACSB 2016a). This movement is linked to the attainment of sustainable development goals (SDGs) initiated by the United Nations (2015). As pointed out in the AACSB report, with this new future role 
of business, ethics education will undergo a transformation in the way it is presented in the curriculum to respond to the greater and wider global challenges faced nowadays. The increasing role of business also rings true for the accounting profession. In the context of accounting ethics education, students should become more aware of the impact of ethical issues on broader stakeholders, including the society (Heller \& Heller 2011). Likewise, Shaub (2017) introduced a 'wisdom-based accounting ethics course' that is expected to help students solve ethical issues by acknowledging the wide impact ethical decisions may have on other parties, which is facilitated by the student's ability to think long-term. Long before the SDGs and the AACSB report (2016a) were initiated, the ever increasing role of accounting has been noted by McCumber (2005, cited in Williams 2015): "Where accounting's ethical considerations need to focus ... on the boundaries where the individual, the profession, the society, the political and economic order, and the natural world interact."

\section{Concluding Comments}

Besides formulating the proper materials as well as teaching methods, the success of accounting ethics education is also dependent on two other things. First, the much-needed institutional support. As identified in the introduction section, one of the obstacles faced by accounting ethics education is lack of support from the institution. A well-designed plan means nothing if it cannot be implemented. Therefore, institution (may refer to program, department, faculty, or university level) should set the tone at the top and show its commitment to ethics in every levels, or what Lawter, Rua, and Guo (2014) referred to as micro, meso and macro levels of university learning space. Second, the commitment from the students. The success of any program also relies on the subject or participants, in the context of education it is the students. Those students who are willing and committed to learn will be more successful. This is identified by Kurpis, Beqiri and Helgeson (2008) as 'commitment to moral self-improvement'. To conclude, the effectiveness of accounting ethics education depends on many factors; addressed in this paper are the what and how aspects of it. The field has been gaining much attention in the past few years, however much needs to be done, especially with the more demanding and challenging role of accountants in recent era. Some improvements to accounting ethics education, both in short- and long-term were also discussed, which could be explored more in further research.

\section{E. Conclusion, Suggestion, Limitation}

Accounting ethics education is quite a challenging field to teach, due to some impeding factors, such as lack of resources and uncertainty of materials as well as teaching methods. This paper tries to review some literatures as to what and how to teach accounting ethics, to serve as a starting point for academics in developing and improving accounting ethics course. Eleven categories of accounting ethics topics are suggested: ethics theories, judgment and decision making, responsibility of business, regulatory framework, professional codes of conduct, corporate code of ethics and governance, whistleblowing, ethical issues in practice, corporate scandals/ fraud/ earnings management, leadership and other topics. For teaching methods, a number of ways are inventoried: case study, debates/ discussion/ presentation, games, illustrations/ vignettes, independent learning, informal approach, internship, lecture, online learning, project, reading, reflective learning, role playing, sharing by guest speaker and videos/ films. It is expected that by knowing what and how to teach, academics may start to 
think and consider accounting ethics just as important as other accounting technical courses. In addition, there are two areas identified as improvements to accounting ethics education, namely to develop a more principles-based approach and to shift the focus to prevent ethical failures. Academics should bear in mind these two factors when designing accounting ethics course. In the future, a bird's eye view of ethics education in general, including accounting ethics, is needed, in order for it to develop and evolve due to its broad impact to society as well as nature as a whole.

This paper is subject to some limitations. First, it is based only on selected literatures, hence there might be other best practices from other literatures which are not included in this paper. Second, this paper implied a stand-alone accounting ethics course, which may not always be practical to be implemented. Third, there are possibilities that some of the topics and teaching methods suggested in this paper may not be feasible to be implemented due to various reasons. For future research, some areas that can be explored further are: mapping teaching methods to accounting ethics topics, impact of different teaching methods to ethical reasoning and behavior, evaluation of existing ethics course content vs. benchmark, impact of ethics education exposure in university on professional accountants (longitudinal), impact of different accounting ethics topics on ethical reasoning and behavior, research on factors deterring ethical failures, and research on broader perspective of ethics education.

\section{F. References}

AACSB. (2016a). A Collective Vision for Business Education.

AACSB. (2016b). Eligibility Procedures and Accreditation Standards for Accounting Accreditation.

AACSB. (2017). Eligibility Procedures and Accreditation Standards for Business Accreditation.

AACSB Ethics Education Task Force. (2004). Ethics Education in Business Schools.

Abdolmohammadi, M.J. \& Reinstein, A. (2012). Practising accountants' views of the content of accounting ethics courses and course effects on attitudes and behavior. Advances in Accounting Education: Teaching and Curriculum Innovations, 13, 213-236.

Barker, C.R. (2014). An examination of the ethical discourse of the US public accounting profession from a Foucaultian perspective. Journal of Accounting \& Organizational Change, 10, 2, 216-228.

Blanthorne, C. (2017). Designing a theme-based ethics course in accounting. Advances in Accounting Education: Teaching and Curriculum Innovations, 20, 135-140.

Boose, M.A. \& Dean, F.P. (2011). A proposition for effective integration of ethics across the business curriculum. International Business \& Economics Research Journal, 1, 3, 1-8.

Burns, D.J., Tackett, J.A., Wolf, F. (2015). The effectiveness of instruction in accounting ethics education: Another look. Research on Professional Responsibility and Ethics in Accounting, 19, 149-180.

Chawla, S.K., Khan, Z.U., Jackson, R.E., Gray III, A.W. (2015). Evaluating ethics education for accounting students. Management Accounting Quarterly, winter 2015, 16, 2, 16-25.

Christensen, L.J., Peirce, E., Hartman, L.P., Hoffman, W.M., Carrier, J. (2007). Ethics, $C S R$, and sustainability education in the Financial Times top 50 global business 
schools: Baseline data and future research directions. Journal of Business Ethics, 73, 347-368.

Davis, E. (2017). Ethics Within and Throughout. Accessed on December 8, 2017 from https://www.aacsb.edu/blog/2017/august/ethics-within-and-throughout

Dellaportas, S. (2006). Making a difference with a discrete course on accounting ethics. Journal of Business Ethics, 65, 391-404.

Dzuranin, A.C., Shortridge, R.T., Smith, P.A. (2013). Building ethical leaders: A way to integrate and assess ethics education. Journal of Business Ethics, 115, 1, 101114.

Fort, T.L. (2016.) Adding Ethics to the Classroom. Accessed on December 13, 2017 from http://bized.aacsb.edu/articles/2016/01/adding-ethics

Franks, R.A. \& Spalding Jr., A.D. (2013). Business ethics as an accreditation requirement: A knowledge mapping approach. Business Education \& Accreditation, 5, 1, 17-30.

Ghazali, N.A.M. (2015). The influence of a business ethics course on ethical judgments of Malaysian accountants. Journal of Asia Business Studies, 9, 2, 147-161.

Graham, C.M., Kelly, P., Massey, D.W., \& Van Hise, J. (2014). One size does not fit all - different strategies for teaching accounting ethics. Research on Professional Responsibility and Ethics in Accounting, 17, 139-157.

Hejase, H.J., Tabch, H. (2012). Ethics education: An assessment case of the American University of Science and Technology - Lebanon. International Journal of Islamic and Middle Eastern Finance and Management, 5, 2, 116-133.

Heller, N.A. \& Heller, V.L. (2011). Business ethics education: Are business schools teaching to the AACSB Ethics Education Task Force Recommendations? International Journal of Business and Social Science, 30-38.

Holmes, K., Marriott, L., Randal, J. (2012). Ethics and experiments in accounting: A contribution to the debate on measuring ethical behavior. Pacific Accounting Review, 24, 1, 80-100.

Huehn, M.P. (2016). Ethics as a catalyst for change in business education? Journal of Management Development, 35, 2, 170-189.

IAESB. (2017). Handbook of International Education Pronouncements.

IFAC. (2006). Approaches to the Development and Maintenance of Professional Values, Ethics and Attitudes in Accounting Education Programs.

Jackling, B., Cooper, B.J., Leung, P., Dellaportas, S. (2007). Professional accounting bodies' perceptions of ethical issues, causes of ethical failure and ethics education. Managerial Auditing Journal, 22, 9, 928-944.

Jonson, E.P., McGuire, L., Cooper, C. (2016). Does teaching ethics do any good? Education + Training, 58, 4, 439-454.

Kelly, P.T. (2017). Integrating leadership topics into an accounting ethics course preparing students for a challenging profession. Advances in Accounting Education: Teaching and Curriculum Innovations, 20, 141-180.

Klein, G. (2016). Ethics in accounting: A decision making approach. Hoboken, NJ: Wiley.

Klimek, J. \& Wenell, K. (2011). Ethics in accounting: An indispensable course? Academy of Educational Leadership Journal, 15, 4, 107-118.

Koumbiadis, N. \& Pandit, G.M. (2014). Has the AICPA changed the accounting profession for better or worse? The case of educational change. Journal of Accounting \& Organizational Change, 10, 2, 190-215. 
Kurpis, L.V., Beqiri, M.S., Helgeson, J.G. (2008). The effects of commitment to moral self-improvement and religiosity on ethics of business students. Journal of Business Ethics, 80, 447-463.

Lawter, L., Rua, T., Guo, C. (2014). The interaction between learning styles, ethics education, and ethical climate. Journal of Management Development, 33, 6, 580-593.

Levy, D. \& Mitschow, M. (2008). Accounting ethics education: where do we go from here? Research on Professional Responsibility and Ethics in Accounting, 13, 135-154.

McDonald, G.M. (2004). A case example: Integrating ethics into the academic business curriculum. Journal of Business Ethics, 54, 371-384.

Miller, W.F. \& Shawver T.J. (2018). An exploration of the state of ethics in UK accounting education. Journal of Business Ethics, 153, 4, 1109-1120.

Mintz, S.M. \& Morris, R.E. (2014). Ethical obligations and decision making in accounting: Text and cases (3rd ed). New York, NY: McGraw Hill.

O'Leary, C. (2012). Semester-specific ethical instruction for auditing students. Managerial Auditing Journal, 27, 6, 598-619.

Perri, D.F., Callanan, G.A., Rotenberry, P.F., Oehlers, P.F. (2009). Education and training in ethical decision making: comparing context and orientation. Education + Training, 51, 1, 70-83.

Rezaee, Z., Szendi, J., Elmore, R.E. \& Zhang, R. (2015). Corporate governance and ethics education: viewpoints from accounting academicians and practitioners. Advances in Accounting Education: Teaching and Curriculum Innovations, 13, 127-158.

Shapiro, J.P., Hassinger, R.E. (2007). Using case studies of ethical dilemmas for the development of moral literacy: Towards educating for social justice. Journal of Educational Administration, 45, 4, 451-470.

Shaub, M.K. (2017). A wisdom-based accounting ethics course. Advances in Accounting Education: Teaching and Curriculum Innovations, 20, 181-216.

Sisaye, S. (2011). The functional-institutional and consequential-conflictual sociological approaches to accounting ethics education. Managerial Auditing Journal, 26, 3, 263-294.

Taylor, A. (2013). Ethics training for accountants: does it add up? Meditari Accountancy Research, 21, 2, 161-17.

United Nations. (2015). Sustainable development goals. Accessed on September 25, 2018 from https://sustainabledevelopment.un.org/?menu=1300

Utama, S. (2018). No accounting education is complete without values, ethics, \& attitudes. Accessed on May 3, 2018 from https://www.ifac.org/system/files/publications/files/IAESB-Perspectives-SeriesSidharta-Utama.pdf

West, A. (2017). The ethics of professional accountants: an Aristotelian perspective. Accounting, Auditing \& Accountability Journal, 30, 2, 328-351.

West, A. \& Buckby, S. (2018). Ethics education in the qualification of professional accountants: insights from Australia and New Zealand. Journal of Business Ethics, 1-20.

Weybrecht, G. (2016). How to teach students to be ethical. Accessed on December 8, 2017 from https://www.aacsb.edu/blog/2016/december/how-to-teach-studentsto-be-ethical 
14 | Amelia Limijaya

Williams, P.F. (2015). The focus of professional ethics: Ethical professionals or ethical profession? Research on Professional Responsibility and Ethics in Accounting, $14,15-35$. 